\title{
Hydrocarbon degradation potential and plant growth-promoting activity of culturable endophytic bacteria of Lotus corniculatus and Oenothera biennis from a long-term polluted site
}

\author{
Malgorzata Pawlik ${ }^{1}$ - Barbara Cania ${ }^{2}$ - Sofie Thijs ${ }^{3} \cdot$ Jaco Vangronsveld $^{3}$. \\ Zofia Piotrowska-Seget ${ }^{1}$
}

Received: 19 February 2017 / Accepted: 8 June 2017 / Published online: 6 July 2017

(C) The Author(s) 2017. This article is an open access publication

\begin{abstract}
Many endophytic bacteria exert beneficial effects on their host, but still little is known about the bacteria associated with plants growing in areas heavily polluted by hydrocarbons. The aim of the study was characterization of culturable hydrocarbon-degrading endophytic bacteria associated with Lotus corniculatus L. and Oenothera biennis L. collected in long-term petroleum hydrocarbon-polluted site using culture-dependent and molecular approaches. A total of 26 hydrocarbon-degrading endophytes from these plants were isolated. Phylogenetic analyses classified the isolates into the phyla Proteobacteria and Actinobacteria. The majority of strains belonged to the genera Rhizobium, Pseudomonas, Stenotrophomonas, and Rhodococcus. More than $90 \%$ of the isolates could grow on medium with diesel oil, approximately $20 \%$ could use $n$-hexadecane as a sole carbon and energy source. PCR analysis revealed that $40 \%$ of the isolates possessed the P450 gene encoding for cytochrome P450-type alkane hydroxylase (CYP153). In in vitro tests, all endophytic strains demonstrated a wide range of plant growth-promoting traits such as production of indole-3-acetic acid, hydrogen cyanide, siderophores, and phosphate solubilization. More than $40 \%$ of the bacteria carried the gene encoding for the 1aminocyclopropane-1-carboxylic acid deaminase $(a c d S)$. Our
\end{abstract}

Responsible editor: Robert Duran

Małgorzata Pawlik

malgorzata.pawlik@us.edu.pl

1 Department of Microbiology, University of Silesia, Katowice, Poland

2 Research Unit Environmental Genomics, Helmholtz Zentrum München, Munich, Germany

3 Environmental Biology, Centre for Environmental Sciences, Hasselt University, Hasselt, Belgium study shows that the diversity of endophytic bacterial communities in tested plants was different. The results revealed also that the investigated plants were colonized by endophytic bacteria possessing plant growth-promoting features and a clear potential to degrade hydrocarbons. The properties of isolated endophytes indicate that they have the high potential to improve phytoremediation of petroleum hydrocarbon-polluted soils.

Keywords Plant-bacteria interactions $\cdot$ Endophytic bacteria . Petroleum hydrocarbons $\cdot$ Plant growth-promoting mechanisms · Lotus corniculatus L. · Oenothera biennis L.

\section{Introduction}

Over the last decades, plant-endophytic bacteria associations have received considerable attention. These associations play essential roles in beneficial interactions among plants and bacteria, and contribute to the ecological balance between them (Hardoim et al. 2008; Khan et al. 2013; Santoyo et al. 2016). Endophytes reside in plant tissues without any noticeable harmful effects on their host, and numerous studies have illustrated their positive effects on plant growth and development (Gaiero et al. 2013; Khan et al. 2013; Weyens et al. 2009d). As a consequence of their innate plant growth-promoting capabilities, they can contribute to a better adaptation of their host to biotic and abiotic stresses; facilitate the availability of nitrogen, phosphorus, and iron; produce phytohormones; and protect the plant against pathogens (Abbamondi et al. 2016; Compant et al. 2005; Glick et al. 2007; Naveed et al. 2014; Santoyo et al. 2016; Qin et al. 2015). Moreover, endophytes increase the tolerance of plants to contaminants by their degradation and/or detoxification, and reducing plant stress by production of 1-aminocyclopropane-1-carboxylic acid 
(ACC) deaminase (Barac et al. 2004; Gaiero et al. 2013; Huang et al. 2005; Ryan et al. 2008). Therefore, endophytic bacteria were claimed to be of significant importance in effective phytoremediation programs (Barac et al. 2009; Weyens et al. 2009a, b, c, d).

Phytoremediation is a green technology that utilizes plants and their associated microorganisms to clean up polluted soils and (ground)waters, and is considered a promising economical feasible strategy for the removal of organic contaminants from soils (Vangronsveld et al. 2009; Weyens et al. 2009c). Non-regulated disposal of oil sludge, oil extraction, refining, and leakage during storage and transport led to significant soil contamination and accumulation of aliphatic and aromatic hydrocarbons in the environment. Because many petroleum hydrocarbons can exert harmful effects on living organisms, removal of these organic pollutants has been intensively investigated (Huang et al. 2005; Khan et al. 2013; Wang et al. 2008). Recent evidences suggest that a key element for successful phytoremediation is the use of plants that tolerate high levels of contaminants, in combination with beneficial plantassociated endophytic bacteria capable of degrading pollutants (Germaine et al. 2009; Yousaf et al. 2010a, b; Yousaf et al. 2011). Furthermore, it has been shown that plants growing in hydrocarbon-contaminated soil can selectively enhance the prevalence of favorable endophytes containing genes encoding for enzymes responsible for hydrocarbon degradation (Oliveira et al. 2014; Siciliano et al. 2001). Also, other authors demonstrated that the presence of hydrocarbon pollution has led to increased numbers of endophytes with hydrocarbon degradation capabilities (Barac et al. 2009; Oliveira et al. 2014; Taghavi et al. 2009). It appears that exploring the diversity of the plant endophytic community is important for the selection of useful strains for phytoremediation of soils polluted with organics, improving plant adaptation and growth. Due to the broad range of symbiotic interactions between the plant host and its endophytes, their potential has great implications for biotechnological applications during phytoremediation (Khan et al. 2013; Li et al. 2012; PilonSmits 2005). Plant species capable of growing in soils heavily polluted with petroleum hydrocarbons make them a useful tool for phytoremediation purposes. Species used in this study are Lotus corniculatus (bird's-foot trefoil) and Oenothera biennis (common evening-primrose), growing abundantly in a long-term crude oil polluted area in Silesia (Poland). Their high tolerance to hydrocarbon contamination may indicate that the tissues of these plants are colonized by hydrocarbondegrading endophytes that will show more promise for detailed studies and applications. In recent studies, Lotus spp. were shown to possess a great potential to adapt to a number of abiotic stresses, making them suitable candidates for phytoremediation of degraded environments (Escaray et al. 2012; Yousaf et al. 2010a, b). Previously, alkane-degrading endophytic bacteria were isolated from L. corniculatus growing under laboratory conditions (Oliveira et al. 2014; Yousaf et al. 2010a). However, these studies were lacking important information about the composition of endophytic bacterial communities of $L$. corniculatus spontaneously colonizing heavily polluted environments. Also, much remains to be explored about the abundance and diversity of the endophytic bacteria associated with wild growing $O$. biennis. To the best of our knowledge, this is the first report describing the petroleum hydrocarbon-degrading endophytic bacteria of O. biennis.

Therefore, the aim of the study was to assess the potential of endophytes isolated from L. corniculatus and O. biennis for petroleum hydrocarbon degradation. Moreover, the composition of endophytic communities isolated from both plants and plant growth promotion potential of endophytes were investigated.

\section{Material and methods}

\section{Isolation of endophytic bacteria and genotypic characterization}

L. corniculatus (bird's-foot trefoil) and O. biennis (common evening-primrose) were collected from a long-term polluted site located in Czechowice-Dziedzice, Silesia, Southern Poland ( $\left.49^{\circ} 54^{\prime} 49.0^{\prime \prime} \mathrm{N}, 19^{\circ} 01^{\prime} 01.9^{\prime \prime} \mathrm{E}\right)$. The total petroleum hydrocarbons (TPH) content of the soil was $7460.5 \pm 272.9 \mathrm{mg} \mathrm{kg}^{-1}$ dry soil (PN-EN ISO 16703:2011). The detailed soil characteristic was published previously (Pacwa-Płociniczak et al. 2016). Plants were sampled with soil adhering to the roots to a depth of $0-20 \mathrm{~cm}$ around a waste lagoon with acidic, highly weathered petroleum sludge. The plants were collected with adjusted soil in five replicates and transferred to the laboratory. The plants were kept in room temperature, and soil moisture was adjusted to constant level. During 5 days, the endophytic bacteria were isolated according the procedure described in this paper.

The plants were divided into roots, shoots, and leaves. Roots were shaken with $2 \%$ Tween 80 (water solution) to remove the adhering soil, and then transferred to a solution for surface sterilization. The pieces of roots were submerged in $0.01 \%$ active sodium hypochlorite, $10 \%$ hydrogen peroxide, $70 \%$ ethanol for $2 \mathrm{~min}$, and rinsed three times with sterile distilled water. The stems and leaves were surface sterilized using 10\% hydrogen peroxide, and $70 \%$ ethanol for $2 \mathrm{~min}$, and rinsed three times with sterile distilled water. The sterilization efficiency was confirmed by plating $100 \mu \mathrm{L}$ of last washing water onto a TSA medium. Subsequently, the roots, stems, and leaves were macerated with $0.9 \% \mathrm{NaCl}$.

Two approaches were used to isolate hydrocarbondegrading endophytic bacteria. In the first strategy, the macerate of plant was directly plated on solid M9 mineral medium 
with crude oil $(1 \%)$ as the sole source of carbon and energy. As a second method, liquid enrichment cultures were used. The macerated plant tissue was added to $100 \mathrm{~mL}$ liquid M9 mineral medium containing crude oil at the concentration of $1 \%$. The flasks were incubated with shaking $(120 \mathrm{rpm})$ for 7 days at $28{ }^{\circ} \mathrm{C}$. Then, the enrichment culture was spread on a solid M9 mineral medium with crude oil (1\%). All plates were incubated for 7 days at $28^{\circ} \mathrm{C}$. Morphologically distinct bacterial colonies were selected, purified, and stored at $-20{ }^{\circ} \mathrm{C}$.

From each isolated endophytic strain, DNA was extracted using the DNeasy Blood and Tissue Kit (Qiagen, Venlo, Netherlands). The 27F (5' AGAGTTTGATCCTGGCTCAG $3^{\prime}$ ) and 1392R (5' ACGGGCGGTGTGTRC 3') primers were used for the PCR amplification of the 16S rRNA gene. The PCR master mix consisted of: DNA template, $1 \times$ High Fidelity PCR buffer (Invitrogen, Carlsbad, CA, USA), $0.2 \mathrm{mM} \mathrm{L}^{-1}$ of dNTP, $2 \mathrm{mM} \mathrm{L}^{-1} \mathrm{MgCl}_{2}, 0.2 \mu \mathrm{M} \mathrm{L}^{-1}$ each of the forward and reverse primers, and $1 \mathrm{U}$ of High Fidelity Platinum Taq DNA polymerase (Invitrogen, Carlsbad, CA, USA) per $50 \mu \mathrm{L}$. The PCR conditions were denaturation at $94{ }^{\circ} \mathrm{C}$ for $5 \mathrm{~min}, 30$ cycles of $94{ }^{\circ} \mathrm{C}$ for $1 \mathrm{~min}, 54{ }^{\circ} \mathrm{C}$ for $45 \mathrm{~s}$, and $72{ }^{\circ} \mathrm{C}$ for $1.5 \mathrm{~min}$, followed by final extension of $10 \mathrm{~min}$ at $72{ }^{\circ} \mathrm{C}$. The PCR products $(20 \mu \mathrm{L})$ were digested for $2 \mathrm{~h}$ at $37^{\circ} \mathrm{C}$ with $1 \mathrm{U}$ of the four-base-specific restriction endonuclease HpyCH4 IV in 1× NEB buffer (New England Biolabs). Amplified ribosomal DNA restriction analysis (ARDRA) was performed using obtained digestion fragments. They were separated and visualized by electrophoresis in a $1.5 \%$ agarose gel with GelRed (VWR, Leuven, Belgium). The same ARDRA banding patterns were grouped and representative patterns were selected for sequencing. The obtained $16 \mathrm{~S}$ ribosomal DNA (rDNA) sequences from Macrogen (Amsterdam, the Netherlands) were compared with nucleotide sequences in the National Center for Biotechnology Information (NCBI) database using the Basic Local Alignment Search Tool (BLAST). A phylogenetic tree was constructed with the neighbor-joining method by the software MEGA 6.0. Bootstrap analysis was performed based on 1000 replicates. The sequences of 16 selected isolates were submitted to the NCBI GenBank database under accession numbers from KU726257 to KU726272.

\section{Plant growth-promoting and other characteristics}

The ability of isolates to solubilize inorganic phosphate was tested using Pikovskaya agar medium. After 7 days of incubation at $28^{\circ} \mathrm{C}$, the presence of clear halos around colonies indicated a positive reaction, and considered as resulting from the utilization of tricalcium phosphate (Pikovskaya 1948).

The indole-3-acetic acid (IAA) production was estimated by a colorimetric method using Salkowski's reagent as described by Patten and Glick (2002). Concentration of IAA produced was estimated against standard curve of IAA in the range of $10-100 \mu \mathrm{g} \mathrm{m}^{-1}$. Hydrogen cyanide (HCN) production was examined by adapting the method of Lorck (1948). Bacteria were cultured on nutrient broth (NB) supplemented with glycine at the concentration of $4.4 \mathrm{~g} \mathrm{~L}^{-1}$ at $28^{\circ} \mathrm{C}$ for 4 days. Then bacteria were plated on the same solid medium and a Whatman filter paper soaked in solution of $2 \%$ $\mathrm{Na}_{2} \mathrm{CO}_{3}$ in $0.5 \%$ picric acid was placed on top of the medium. Plates were sealed with parafilm and incubated at $28{ }^{\circ} \mathrm{C}$ for 7 days. Production of HCN was indicated by color change of filter paper from yellow to orange-brown.

Siderophore release was evaluated on a Chrome Azurol S (CAS) agar medium as proposed by Schwyn and Neilands (1987). A positive reaction was considered when the color of CAS medium was changed from blue to yellow or orange.

The ACC deaminase gene $a c d S$ was PCR-amplified using primers F1936 (forward) 3' GHGAMGACTGCAA YWSYGGC 5', F1938 (reverse) 3' ATCATVCCVTGCATB GAYTT 5', F1939 (reverse) 3' GARGCRTCGAY VCCRATCAC 5' (Blaha et al. 2006). The PCR mixture and conditions were prepared as described before (Kukla et al. 2014; Pawlik and Piotrowska-Seget 2015).

To determine the cellulase production, the bacterial cultures were plated on medium with carboxymethyl cellulose as the sole carbon source. After 7 days of incubation at $28^{\circ} \mathrm{C}$, the Lugol's iodine was spread on the plate surface and yellow zones formed around the colonies indicated positive results (Pointing 1999).

To assess the swarming motility of bacterial strains, a semisolid $0.2 \% \mathrm{NB}$ agar was used. A diffuse zone of growth around the inoculation site at the center of the plate was considered as a positive result. The halo zone of growth was observed macroscopically after $24-48 \mathrm{~h}$ of incubation at $28^{\circ} \mathrm{C}$.

In all plant growth-promoting (PGP) tests, Enterobacter intermedius $\mathrm{MH} 8 \mathrm{~b}$ and Escherichia coli $\mathrm{DH} 5 \alpha$ were used as the positive and negative controls, respectively (Płociniczak et al. 2013).

The emulsification activity was determined using the emulsification index (E24). The isolated endophytic strains were cultured on LB broth, M9 mineral medium with crude oil $(1 \%)$, or $n$-hexadecane $(1 \%)$ at $120 \mathrm{rpm}$ on a rotary shaker. After 7 days at $28{ }^{\circ} \mathrm{C}$, the cultures were centrifuged $(10,600 \times g, 5 \mathrm{~min})$ and $2 \mathrm{~mL}$ of supernatant were vigorously vortexed with $3 \mathrm{~mL}$ of substrate (diesel oil, $n$-hexadecane, or para-xylene). After $24 \mathrm{~h}$, the height of the emulsion was measured. The E24 was presented as a percentage of height of the emulsified layer $(\mathrm{mm})$ divided by total height of the liquid column (mm). In all measurements, the obtained results were compared with a positive control. This positive control was prepared by vortexing $2 \mathrm{~mL}$ of $5 \%$ solution of SDS (sodium dodecyl sulfate) and $3 \mathrm{~mL}$ of substrate (diesel oil, $n$ hexadecane, or para-xylene). 


\section{Potential degradation of hydrocarbons and hydrocarbon-degradation genes}

The ability to use petroleum hydrocarbons by isolated bacteria as a sole carbon and energy source was checked on a $40-\mathrm{mL}$ liquid M9 mineral medium containing $1 \%$ of crude oil, diesel oil, $n$-hexadecane, or para-xylene. No other carbon source was added to the medium, and each treatment was performed with three replicates. The strains were incubated at $28{ }^{\circ} \mathrm{C}$ for 7 days, and their growth was compared with overall growth on NB. The growth kinetic in liquid media was performed to evaluate the growth of the strains with hydrocarbons as a sole carbon source. Results were considered positive when the optical densities of M9 and NB were similar.

The isolates were analyzed for the presence of specific genes encoding enzymes involved in hydrocarbon degradation, e.g., alkB (alkane monooxygenase), alkH (alkane hydroxylase), $P 450$ (cytochrome P450-type alkane hydroxylase, CYP153), C23O (catechol-2,3-dioxygenase), and pah (alpha subunit of the PAH-ring hydroxylating dioxygenases). DNA extraction and PCR conditions were described previously (Kukla et al. 2014).

\section{Results}

\section{Isolation of endophytic bacteria and genotypic characterization}

Collected plants were growing in soil containing high levels of petroleum hydrocarbons $\left(7460.5 \pm 272.9 \mathrm{mg} \mathrm{kg}^{-1}\right.$ dry soil). In order to obtain hydrocarbon-degrading endophytic bacteria, only endophytes able to grow on M9 medium with $1 \%$ crude oil were isolated. Based on morphological characteristics 26 different endophytic strains were selected from roots, stems, and leaves of $L$. corniculatus and $O$. biennis.

The isolates were identified based on sequencing of their $16 \mathrm{~S}$ rDNA genes. To compare the genetic diversity, strains were grouped according to their ARDRA profiles (Table 1). Therefore, 16 strains presenting different ARDRA patterns were sequenced and identified by BLAST (similarities of $\geq 98 \%$ ), and a phylogenetic tree was constructed (Fig.1).

Alphaproteobacteria, Gammaproteobacteria, and Actinobacteria were observed in both plant species. However, Betaproteobacteria were found only in L. corniculatus and were represented by Delftia sp. Gammaproteobacteria comprised the majority of the isolated strains and were the predominant group in both investigated plant species (Fig. 2). Bacterial isolates belonging to the genera Rhizobium and Rhodococcus were the most abundant in tissues of $O$. biennis. Pseudomonas sp. was the most often isolated from L. corniculatus. Bacteria from the genera Delftia, Serratia, and Tsukamurella were only found in
L. corniculatus. Strains belonging to the genera Rhodococcus and Xanthomonas were the most characteristic endophytic strains for $O$. biennis.

\section{Potential degradation of hydrocarbons and hydrocarbon-degradation genes}

The isolated endophytic strains were investigated for their hydrocarbon degradation potential. Their ability to grow on media containing diesel oil, $n$-hexadecane, and para-xylene as sole carbon sources was evaluated. More than $90 \%$ of all isolates were able to grow on medium with diesel oil. The potential to use $n$-hexadecane as a source of energy and carbon was observed in 16.67 and $28.57 \%$ of the $L$. corniculatus and $O$. biennis associated strains, respectively. All $n$ hexadecane-degrading bacteria belonged to the genera Rhodococcus and Tsukamurella. None of tested strains could make use of para-xylene as a sole carbon source.

The isolated endophytic bacteria were also screened for the presence of hydrocarbon degradation genes. Only 5 out of the 26 tested strains, namely Pseudomonas mandelii 6FXS, and Rhodococcus sp. (4WK, 5WK, 6.1WK, 7WK) presented a positive PCR result with alkB primers. The appearance of a positive PCR result for the alkH gene was observed for six strains belonging to the genera Tsukamurella and Rhodococcus. The gene P450 responsible for the production of cytochrome P450-type alkane hydroxylase (CYP153) was detected in 41.67 and $42.86 \%$ L. corniculatus and O. biennis associated strains, respectively. Further, none of tested strains possessed genes encoding for catechol-2,3-dioxygenase $(\mathrm{C} 23 \mathrm{O})$, and the alpha subunit of the PAH-ring hydroxylating dioxygenases (pah).

\section{Plant growth-promoting and other characteristics}

All isolated endophytic strains were screened for their plant growth-promoting traits. The obtained results are summarized in Table 2.

The test for tricalcium phosphate solubilization revealed that $58.33 \%$ of the L. corniculatus isolates could produce a halo zone on Pikovskaya medium. One strain, Pseudomonas sp. 2FXS, even produced a clear halo with more than $10 \mathrm{~mm}$ diameter. $28.57 \%$ of the endophytic strains from $O$. biennis showed able to solubilize phosphate in vitro but with low efficiency ( $1.3 \pm 0.6$ up to $3.0 \pm 0.0 \mathrm{~mm}$ of clear zone).

All tested strains produced IAA in the presence of tryptophan. The IAA production ranged from $1.9 \pm 0.2$ up to $62.6 \pm 5.2 \mu \mathrm{g} \mathrm{mL}^{-1}$ of IAA for isolates of $L$. corniculatus and from $1.3 \pm 0.0$ up to $29.6 \pm 1.0 \mu \mathrm{g} \mathrm{mL}^{-1}$ of IAA for strains originating from $O$. biennis. The highest productions were found for three strains isolated from the stem of L. corniculatus: Delftia lacustris 5FXS, Delftia lacustris 6.1XS, and Rhizobium sp. 1XS, which produced $62.6 \pm 5.2$, 
Table 1 Based on ARDRA profiles, 16 bacteria represented different clusters of patterns were selected and identified based on 16S rDNA gene sequencing

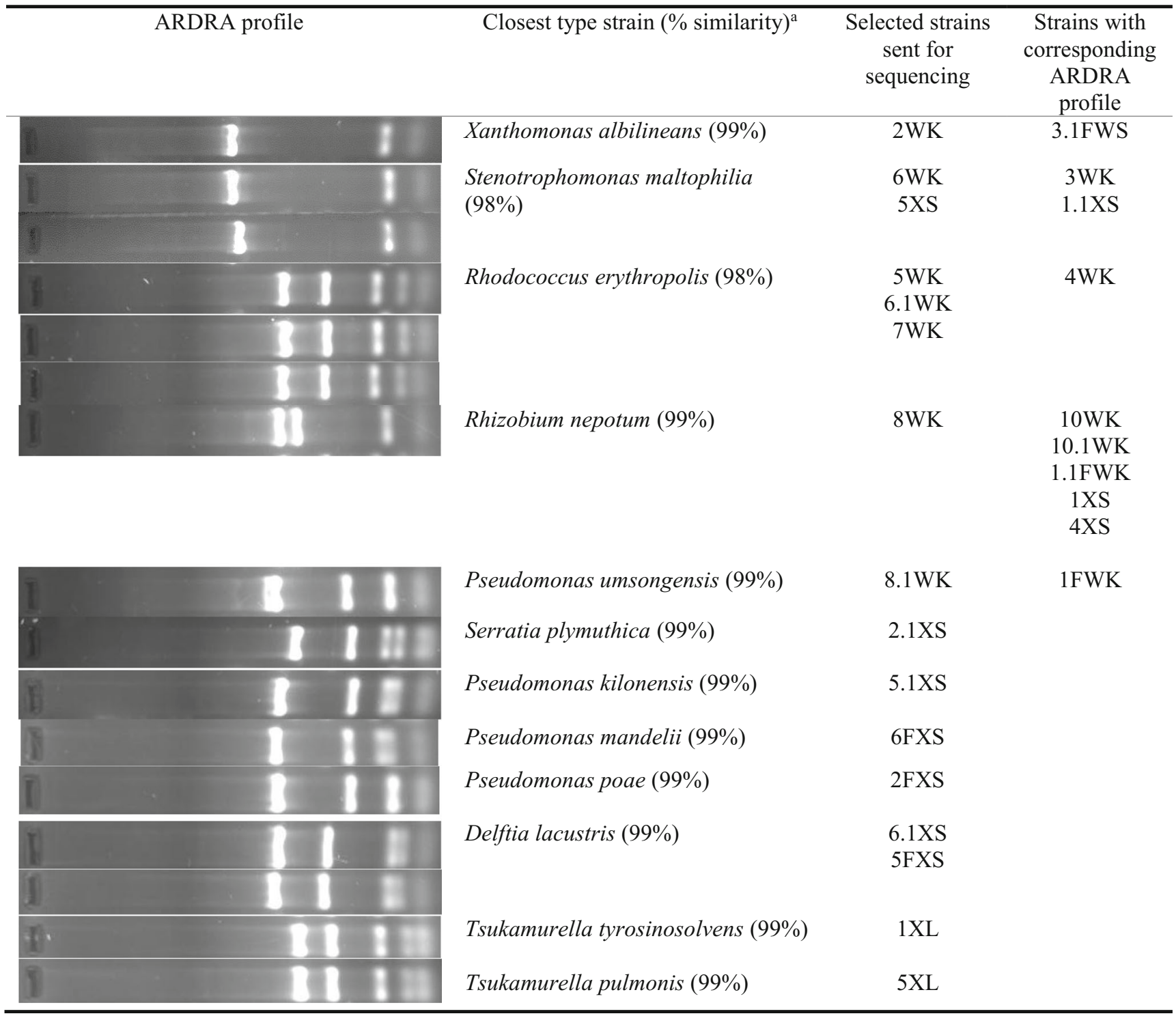

${ }^{\text {a } I d e n t i f i c a t i o n ~ b a s e d ~ o n ~ 16 S ~ r R N A ~ g e n e ~ s e q u e n c i n g ~}$

$59.9 \pm 4.0$, and $35.9 \pm 3.7 \mu \mathrm{g} \mathrm{mL}^{-1}$ of IAA, respectively. In comparison, strains Rhodococcus erythropolis $7 \mathrm{WK}$, Rhodococcus erythropolis 5WK, and Rhodococcus sp. 4WK isolated from roots of $O$. biennis showed lower IAA production potentials of $1.3 \pm 0.0,1.4 \pm 0.1$, and $1.8 \pm 0.1 \mu \mathrm{g} \mathrm{mL}^{-1}$ IAA, respectively.

The ability of the endophytic bacteria to control pathogens by producing HCN was tested. As shown in Table 2, respectively, 83.33 and $64.29 \%$ of the endophytes isolated from L. corniculatus and O. biennis could synthesize HCN.

Siderophore production was observed in higher numbers of L. corniculatus-associated endophytic strains (50\%) (Table 2). Among the isolates from O. biennis, only for $14.29 \%$ a positive result was observed. Several strains could not grow on the CAS medium.

The ACC deaminase production potential of the strains was evaluated based on the PCR amplification of the acdS gene. A positive PCR result was obtained for, respectively, 41.67 and $42.86 \%$ of the strains isolated from L. corniculatus and O. biennis (Table 2).

The potential plant colonization abilities of the endophytic strains were evaluated based on their cellulase activity and motility. The percentages of cellulase producers among L. corniculatus and $O$. biennis isolates were 47.67 and $64.29 \%$, respectively (Table 2). In this test, endophytes of L. corniculatus produced larger halo zones than those of 


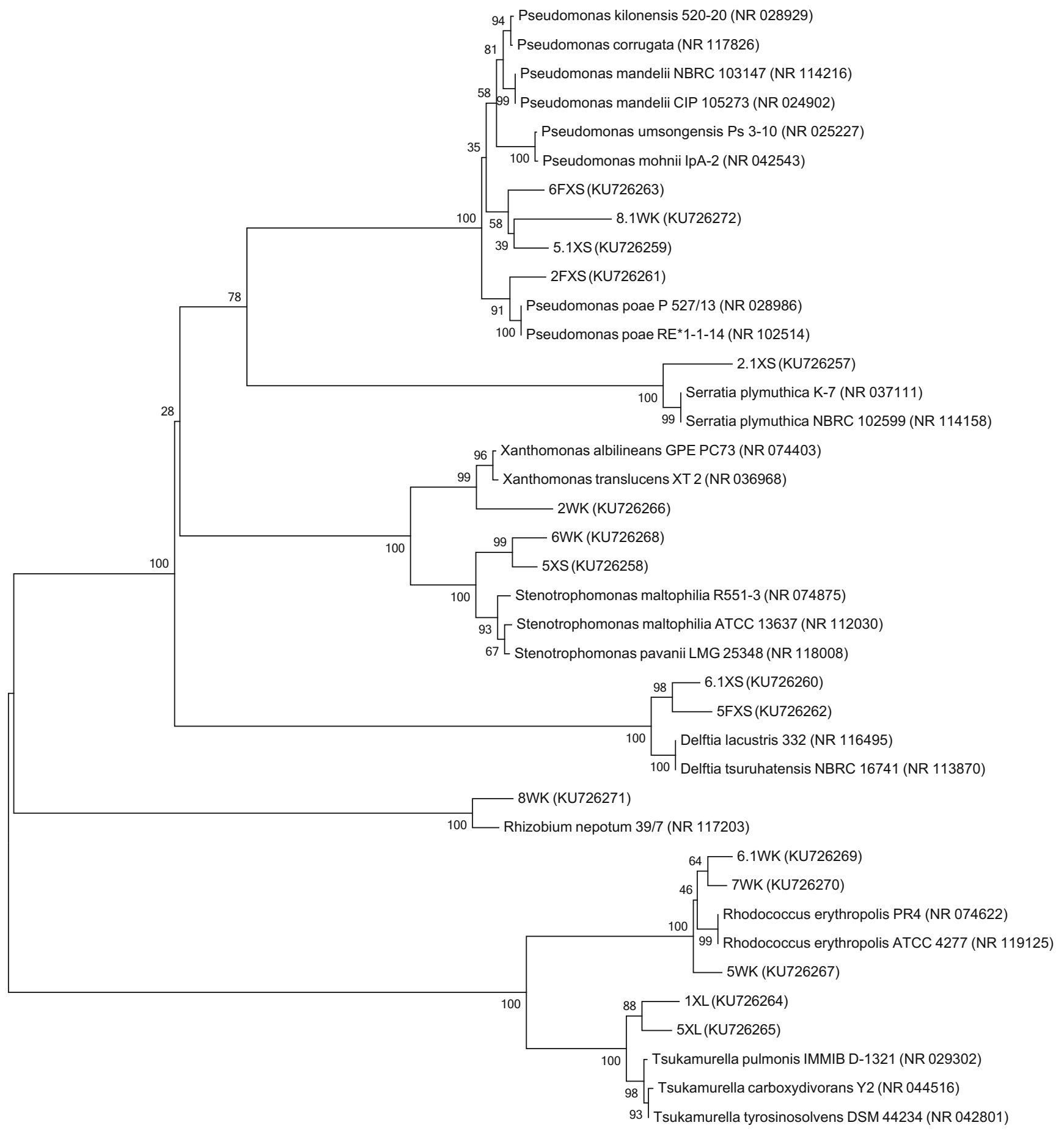

0.02

Fig. 1 Neighbor-joining phylogenetic tree of partial 16S rDNA sequences of endophytic bacteria isolated from L. corniculatus and O. biennis. GenBank accession numbers of the strains are shown in

O. biennis and were in the range of $4.7 \pm 0.6$ up to $15.3 \pm 2.1 \mathrm{~mm}$. With regard to their plant colonization capacities, all isolates were also screened using a swarming motility assay. $83.33 \%$ of the L. corniculatus associated strains and parentheses. The bar represents 0.02 substitutions per site; bootstrap values $(n=1000)$ are displayed. The tree was generated using the MEGA 6.0 software

$71.43 \%$ of the strains isolated from $O$. biennis showed positive for motility.

Due to the hydrophobic nature of petroleum hydrocarbons, the endophytic strains were tested for their emulsification 
Fig. 2 The graphs showing the classification of $L$. corniculatus and $O$. biennis endophytic bacteria to the Alpha-, Beta-, Gammaproteobacteria, or Actinobacteria. The percentages indicate the relative abundance of isolates that were present in the tested plants

\section{Lotus corniculatus Oenothera biennis}

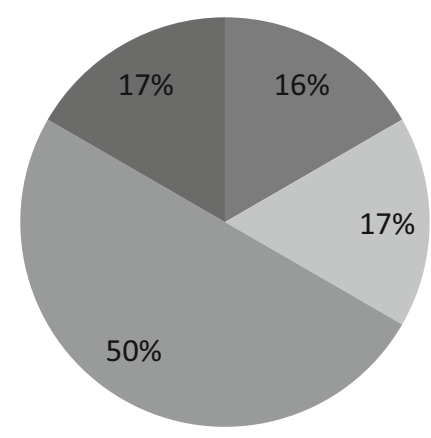

Alphaproteobacteria

Betaproteobacteria

Gammaproteobacteria

- Actinobacteria capacity which could be connected with biosurfactant production. Only six isolates (Serratia plymuthica 2.1XS, Delftia lacustris 6.1XS, Rhodococcus sp. 4WK, Rhodococcus erythropolis $6.1 \mathrm{WK}$, Rhizobium nepotum $8 \mathrm{WK}$, and Pseudomonas umsongensis $8.1 \mathrm{WK}$ ) showed emulsification abilities (Table 3). Rhodococcus sp. 4WK demonstrated the highest emulsification capability against diesel oil $(\mathrm{E} 24=52.78 \%), n$-hexadecane $(\mathrm{E} 24=52.78 \%)$, and paraxylene $(\mathrm{E} 24=58.33 \%)$. The supernatant obtained after growing strain $R$. erythropolis $6.1 \mathrm{WK}$ on M9 medium with $n$ hexadecane, showed emulsification activities against diesel oil $(\mathrm{E} 24=50 \%)$ and para-xylene $(\mathrm{E} 24=50 \%)$, but not for $n$-hexadecane. In the case of other strains, emulsification capabilities were observed after their growth on the M9 medium with crude oil. These strains exhibited emulsification activity only against para-xylene (Table 3 ).

\section{Discussion}

The study of endophytic bacteria associated with plants spontaneously colonizing long-term petroleum hydrocarbonpolluted soils is of high significance. It appears that bacteria associated with these plants exhibit several beneficial traits involved in increasing the availability of nutrients, degradation of pollutants, and production of active metabolites and phytohormones (Andreolli et al. 2013; Ho et al. 2012; Porteous-Moore et al. 2006; Sun et al. 2014a, 2014b).

Our investigation of the culturable hydrocarbon-degrading endophytic bacteria associated with $L$. corniculatus and $O$. biennis indicated that the tissues of these plant species were mainly inhabited by strains belonging to the Gammaproteobacteria with a high predominance of Pseudomonas sp. (Fig. 2). Similar results were reported for the culturable bacterial endophytes isolated from Solidago canadensis collected in an oil area that had been in operation since the mid nineteenth century (Lumactud et al. 2016). Representatives of the genus Pseudomonas are frequently reported plant endophytes and are known for their great abilities to promote plant growth, degrade xenobiotic compounds, induce resistance in plants, or enhance phytoremediation (Compant et al. 2005; Gómez-Lama et al. 2014; Khan et al. 2013; Preston 2004; Sessitsch et al. 2013; Sun et al. 2014a).

In general, the culturable endophytic bacterial communities of $L$. corniculatus and $O$. biennis growing in petroleum hydrocarbons polluted soil were characterized by a low diversity. The isolated strains belonged to two main phyla: Proteobacteria and Actinobacteria (Tables 1 and 2). The domination of Proteobacteria in the endophyte assemblages of Alopecurus aequalis and Oxalis corniculata growing in soil polluted with different levels of polycyclic aromatic hydrocarbons (PAH) was also reported by Peng et al. (2013). Moreover, these authors also found that with increasing levels of PAH, the numbers of endophytic bacteria decreased rapidly. Interestingly, at the same PAH pollution level, the dominant endophytic bacteria in A. aequalis and $O$. corniculata were different (Peng et el. 2013). In our study, we observed a similar trend since Pseudomonas sp. dominated inside L. corniculatus whereas Rhizobium sp. constituted the majority of the culturable endophytes of $O$. biennis. However, Delftia sp., Serratia sp., and Tsukamurella sp. were only detected inside tissues of $L$. corniculatus while Rhodococcus sp. and Xanthomonas sp. were isolated only from O. biennis. It is remarkable that specific bacterial taxa colonize only specific plant species even if they are grown at the same conditions (Lumactud et al. 2016; Phillips et al. 2008). Phillips et al. (2008) showed that Medicago sativa, Lolium perenne, Elymus angustus, Pucinella nuttalliana, and Agropyron elongatum growing in weathered hydrocarbon contaminated soil had distinct endophytic microbial populations with potential to degrade various hydrocarbons. Plant species specificity showed also bacterial endophytic communities from Achillea millefolium, Solidago canadensis, Trifolium aureum, and Dactylis glomerata collected in area contaminated by hydrocarbons (Lumactud et al. 2016). It indicates that despite of hydrocarbons, which are a strong selection pressure, plant species remain a driving factor to endophytic communities (Lumactud et al. 2016). Studies by Tardif et al. (2016) showed 


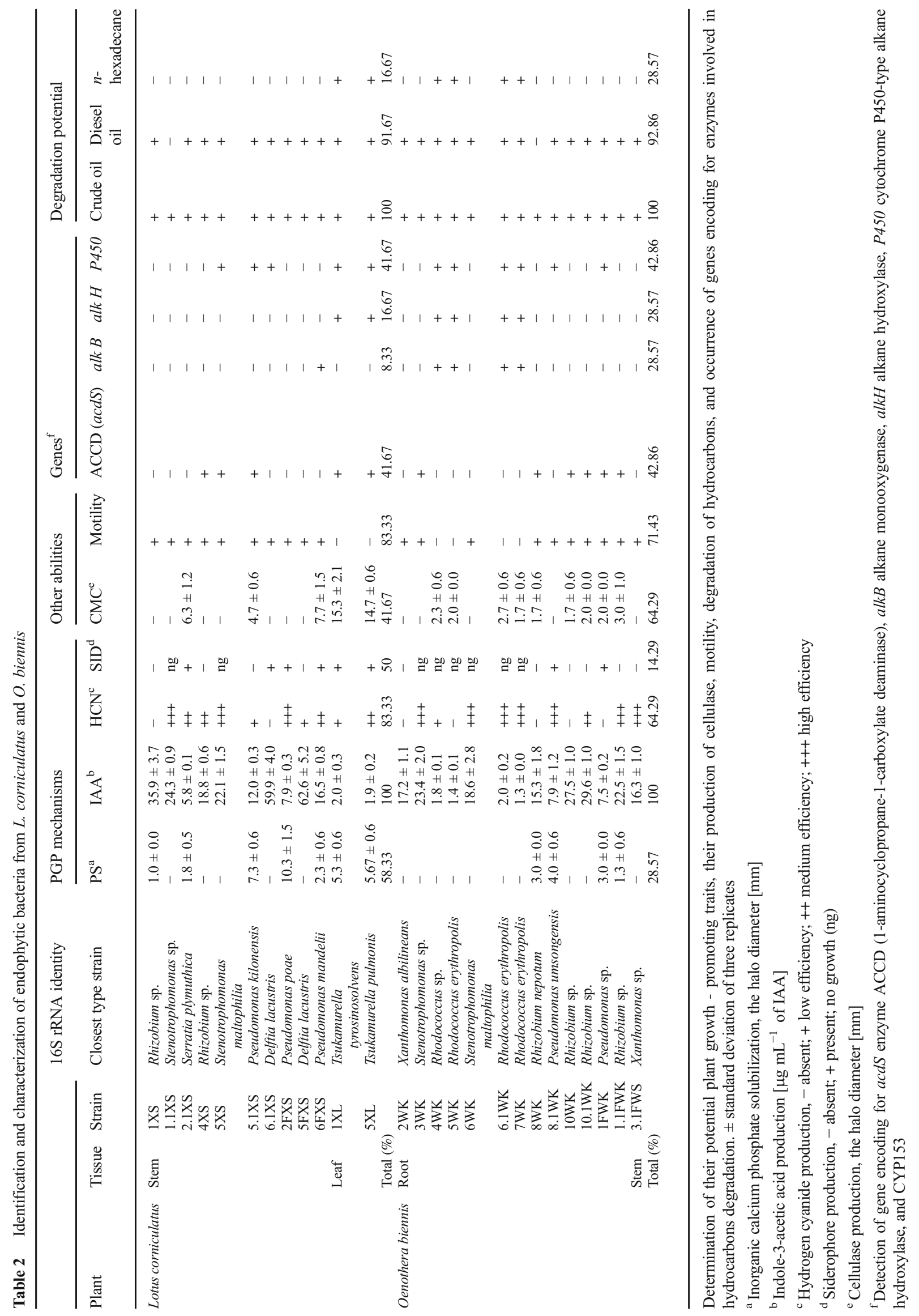


Table 3 Emulsification activities of endophytic bacteria

\begin{tabular}{|c|c|c|c|c|c|c|}
\hline \multirow[t]{3}{*}{ Strain } & \multicolumn{3}{|c|}{ M9 with crude oil } & \multicolumn{3}{|c|}{ M9 with $n$-hexadecane } \\
\hline & \multicolumn{6}{|c|}{ Emulsification index $(\%)$} \\
\hline & $\mathrm{D}$ & $\mathrm{H}$ & $\mathrm{X}$ & $\mathrm{D}$ & $\mathrm{H}$ & $\mathrm{X}$ \\
\hline Serratia plymuthica $2.1 \mathrm{XS}$ & - & - & $41.67 \pm 0.84$ & - & - & - \\
\hline Delftia lacustris $6.1 \mathrm{XS}$ & - & - & $41.67 \pm 0.42$ & - & - & - \\
\hline Rhodococcus sp. 4WK & $52.78 \pm 0.46$ & $52.78 \pm 1.41$ & $58.33 \pm 0.59$ & $47.22 \pm 0.39$ & $47.22 \pm 0.37$ & $52.78 \pm 0.92$ \\
\hline Rhodococcus erythropolis $6.1 \mathrm{WK}$ & - & - & - & $50 \pm 0.53$ & - & $50 \pm 0.45$ \\
\hline Rhizobium nepotum 8WK & - & - & $47.22 \pm 0.53$ & - & - & - \\
\hline Pseudomonas umsongensis $8.1 \mathrm{WK}$ & - & - & $47.22 \pm 0.34$ & - & - & - \\
\hline
\end{tabular}

Strains were cultured in M9 mineral medium with one carbon source (crude oil or $n$-hexadecane). The values of emulsification index were determined for different substrates diesel oil, $n$-hexadecane, and para-xylene. Given are means \pm standard deviation of three replicates

$D$ diesel oil, $H n$-hexadecane, $X p$-xylene

that apart of plants, the level of petroleum hydrocarbon contamination appeared to be an important factor influencing the number and diversity of endophytes. They reported that increasing concentrations of hydrocarbons caused shift in endophytes, favoring putative contaminants degraders and microorganisms with potential to promote plant growth and health. Another key factor that shapes the structure of rhizospheric and also endophytic communities is composition of root exudates (Oliveira et al. 2012; Wael et al. 2014). Different plant species secrete different root exudates which may promote the growth and metabolic properties of microorganisms which are desired by the plants (Andreolli et al. 2013). However, studies on the molecular determinants and interactions in endophytic colonization as well as genetic basis for these processes are still lacking.

Endophytic bacteria can improve the removal of xenobiotics by decreasing the amounts of pollutants in soils (Barac et al. 2004; Germaine et al. 2009). The results of our study have proven that many bacterial endophytes have the potential to degrade various organic contaminants. More than $90 \%$ of the isolates were able to grow on diesel oil. Long-term coevolution between plants and their endophytic bacteria leads to the development of bacteria containing genes encoding hydrolytic enzymes involved in the decomposition of various compounds of plant origin. Several authors characterized endophytic bacteria for their capacities to detoxify BTEX compounds (benzene, toluene, ethylbenzene, and xylene), hydrocarbons such as phenanthrene, fluorene, naphthalene, trinitrotoluene, and PAH (Andreolli et al. 2013; Oliveira et al. 2014; Phillips et al. 2008; Taghavi et al. 2009; Thijs et al. 2014; Yousaf et al. 2010a, 2010b). In this study, many endophytic bacteria exhibited the potential to degrade crude oil, diesel oil, and/or $n$-hexadecane. The occurrence of Rhodococcus sp. and Pseudomonas sp. was interesting due to their already often described abilities for plant growth promotion and hydrocarbon degradation (Kukla et al. 2014; Pawlik and Piotrowska-
Seget 2015). These strains were repeatedly reported as organic pollutant degraders (Porteous-Moore et al. 2006; Zampolli et al. 2014). Our previous studies showed that the dominant cultivable endophytic bacteria inhabiting ryegrass and tall hawkweed growing in petroleum contaminated soil also belonged to the genus Pseudomonas. Members of Rhodococcus genus were also isolated although not in high abundance (Kukla et al. 2014; Pawlik and Piotrowska-Seget 2015).

Almost half of the isolated strains were equipped with the cytochrome P450 hydroxylase gene (CYP153) involved in degradation of short and medium chain-length $n$-alkanes and fatty acids (van Beilen et al. 2006). According to this result, endophytic bacteria may metabolize aliphatic hydrocarbons in plants. On the other hand, various bacteria with genes encoding alkane-degrading enzymes have been found in different environments originally not contaminated with hydrocarbons which suggest also other roles for alkB and/or P450 (CYP153) genes. For example, plant envelopes consist of cuticular waxes composed of long-chain alkanes and by consequence, the ability to degrade alkanes is considered an important first step for endophytic bacteria to enter the plant (Nie et al. 2014; van Bogaert et al. 2011).

One of the limiting factors in bacterial degradation of petroleum hydrocarbons is their hydrophobicity (Kosaric 2001; Pacwa-Płociniczak et al. 2011). Some bacteria produce biosurfactants, increasing the bioavailability of hydrophobic molecules to microorganisms and their further biodegradation. In this study, biosurfactant producers belonged to the genera Serratia, Delftia, Rhodococcus, Rhizobium, and Pseudomonas. Rhodococcus sp. 4WK showed able to emulsify diesel oil, $n$-hexadecane, and para-xylene with high efficiency (Table 3). These emulsification capabilities suggest that these endophytic strains may contribute to the removal of petroleum hydrocarbons by increasing their accessibility. However, due to the different structures of biosurfactants, they 
may play diverse roles in nature. They can inhibit the growth of pathogen, support colonization of plant tissue, improve motility, and improve physical access of enzymes involved in cell wall degradation to the plant surface (Andersen et al. 2003; Raaijmakers et al. 2006; Velho et al. 2011). Hence, biosurfactant production may be another mechanism important in endophytic behavior.

The cellulase secretion and motility of endophytic bacteria may help in the process of plant colonization and spread of bacteria in the host plant. Verma et al. (2001) and Pereira et al. (2016) described the cell wall-degrading enzymes from endophytic bacteria, demonstrating their potential for plant tissues colonization. The ability of bacterial strains to colonize roots appears to be crucial for a close interaction between plants and bacteria especially in hazardous environments. Germaine et al. (2009) suggested that the low ability of Pseudomonas putida G7 to colonize roots might explain the weak phytoprotection effect of this strain in a naphthalene-polluted soil. On the other hand, the study of Andreolli et al. (2013) demonstrated that the PAH-degrading Burkholderia fungorum DBT1 might colonize roots that increased phytoremediation efficiency of PAH. In our study, cellulase production was detected in a high number of endophytic strains $(41.67 \%$ L corniculatus, $64.29 \%$ O. biennis), suggesting that this trait is closely related to endophytic behavior.

Bacterial strains with PGP capabilities have important functions for plants growing in stressful environments polluted with hazardous compounds. For their further use in phytoremediation studies, strain selection should be based on their potential to promote plant growth and hydrocarbon degradation.

The most important PGP mechanism of endophytic bacteria seems to be IAA production. All strains that we isolated were IAA producers (Table 2). Similarly, other authors observed that a vast majority of endophytic bacteria synthesized IAA (Etesami et al. 2014; Kukla et al. 2014; Pawlik and Piotrowska-Seget 2015; Pereira et al. 2016; Xu et al. 2016). The application of these strains could contribute to improve root proliferation and elongation that is crucial during phytoremediation as well as in growth and development of economical important crops such as potatoes, maize, and rice (Garbeva et al. 2001; Ikeda et al. 2010; Seghers et al. 2004). An increased formation of root hairs was observed in Arabidopsis thaliana seedlings after inoculation with all IAA producing endophytic strains while from the rhizospheric strains, only 50\% induced a similar effect (Abbamondi et al. 2016). Furthermore, strains with the ability to produce IAA seem to better colonize plant roots than other strains. Etesami et al. (2014) reported a strong correlation between IAA production by bacteria and their plant colonization efficiency. IAA-producing endophytic strains colonized rice seedlings better in comparison with soil bacteria. However, both positive and negative effects of IAA on plant roots development and growth have been reported (Zúniga et al. 2013). This is linked with the amounts of IAA produced by the bacteria. The high IAA producer strain Pantoea sp. FF34 induced less root biomass in comparison with strains produced markedly lower concentrations of IAA (Naveed et al. 2014).

Strains possessing ACC deaminase activity attract much attention as plant growth-promoting bacteria. This enzyme utilizes the precursor of ethylene that results in the decreasing of plants ethylene concentration and limiting its negative influence on plant growth (Glick et al. 2007; Hardoim et al. 2008). Etesami et al. (2014) observed a significant relationship among IAA and ACC deaminase production for endophytic bacteria which makes them suggesting that these PGP traits may be critical for endophytic and rhizospheric competence. Indeed, in the present study, almost half of isolates showed the potential to produce ACC deaminase as demonstrated by the positive PCR results ( $a c d S$ gene). Plants growing in contaminated soils poor in nutrients need rhizospheric and endophytic bacteria that are able to produce phytohormones and improve the nutrient status of the host (Thijs et al. 2014). ACC deaminase-producing bacteria may reduce stress symptoms, stimulate the proliferation of roots, and promote the development of an extensive root system. These activities may increase contaminant uptake and their further biodegradation by plants or other bacteria (Arshad et al. 2007; Qin et al. 2015). For example, strain Pantoea sp. BTRH79 which possesses ACC deaminase activity improved plant fitness and growth in the presence of diesel contaminants (Arslan et al. 2014). Burkholderia phytofirmans PsJN with a deleted fragment of the acdS gene lost its ACC deaminase activity and ability to promote roots growth of canola (Sun et al. 2009).

\section{Conclusion}

In order to exploit endophytic bacteria for improving phytoremediation efficiency, they should be well characterized. A better knowledge of these bacteria may allow utilizing them to increase remediation polluted soils. Plant growthpromoting and hydrocarbon-degrading endophytic bacterial strains were isolated from the plant species L. corniculatus and $O$. biennis. Our study indicated that all strains tested positive for at least one PGP trait and possessed genes encoding for the hydrocarbon degradation enzymes. Several strains were able to grow in the presence of crude oil, diesel oil, and to a lesser-extent $n$-hexadecane. In addition, our data enable to select endophytic bacterial strains which could enhance phytoremediation of hydrocarbon-polluted sites.

Acknowledgements The study was financed by the National Science Centre, grant 2013/09/N/NZ9/01606. The work was also supported by the Hasselt University Methusalem grant 08M03VGRJ. 
M. Pawlik is a scholarship holder within the DoktoRIS project-scholarship program for the innovation of the Silesia region, supported by the European Community from the European Social Fund.

Open Access This article is distributed under the terms of the Creative Commons Attribution 4.0 International License (http:// creativecommons.org/licenses/by/4.0/), which permits unrestricted use, distribution, and reproduction in any medium, provided you give appropriate credit to the original author(s) and the source, provide a link to the Creative Commons license, and indicate if changes were made.

\section{References}

Abbamondi GR, Tommonaro G, Weyens N, Thijs S, Sillen W, Gkorezis P, Iodice C, Rangel WM, Nicolaus B, Vangronsveld J (2016) Plant growth-promoting effects of rhizospheric and endophytic bacteria associated with different tomato cultivars and new tomato hybrids. Chem Biol Technol Agric 3:1. doi:10.1186/s40538-015-0051-3

Andersen JB, Koch B, Nielsen TH, Sørensen D, Hansen M, Nybroe O, Christophersen C, Sørensen J, Molin S, Givskov M (2003) Surface motility in Pseudomonas sp. DSS73 is required for efficient biological containment of the root-pathogenic microfungi Rhizoctonia solani and Pythium ultimum. Microbiology 149:37-46

Andreolli M, Lampis S, Poli M, Gullner G, Biró B, Vallini G (2013) Endophytic Burkholderia fungorum DBT1 can improve phytoremediation efficiency of polycyclic aromatic hydrocarbons. Chemosphere 92:688-694

Arshad M, Saleem M, Hussain S (2007) Perspectives of bacterial ACC deaminase in phytoremediation. Trends Biotechnol 25:356-362

Arslan M, Afzal M, Amin I, Iqbal S, Khan QM (2014) Nutrients can enhance the abundance and expression of alkane hydroxylase CYP153 gene in the rhizosphere of ryegrass planted in hydrocarbon-polluted soil. PLoS One 9(10):e111208. doi:10.1371/ journal.pone. 0111208

Barac T, Taghavi S, Borremans B, Provoost A, Oeyen L, Colpaert JV, Vangronsveld J, van der Lelie D (2004) Engineered endophytic bacteria improve phytoremediation of water-soluble, volatile, organic pollutants. Nat Biotechnol 22:583-588

Barac T, Weyens N, Oeyen L, Taghavi S, van der Lelie D, Dubin D, Spliet M, Vangronsveld J (2009) Application of poplar and its associated microorganisms for the in situ remediation of a BTEX contaminated groundwater plume. Int J Phytoremediation 11:416-424

Blaha D, Prigent-Combaret C, Mirza MS, Moenne-Loccoz Y (2006) Phylogeny of the 1-aminocyclopropane-1-carboxylic acid deaminase-encoding gene $a c d S$ in phytobeneficial and pathogenic Proteobacteria and relation with strain biogeography. FEMS Microbiol Ecol 56:455-470

Compant S, Duffy B, Nowak J, Clement C, Barka EA (2005) Use of plant growth-promoting bacteria for biocontrol of plant diseases: principles, mechanisms of action, and future prospects. Appl Environ Microbiol 71(9):4951-4959

Escaray FJ, Menendez AB, Garriz A, Pieckenstain FL, Estrella MJ, Castagno LN, Carrasco P, Sanjuan J, Ruiz OA (2012) Ecological and agronomic importance of the plant genus Lotus. Its application in grassland sustainability and the amelioration of constrained and contaminated soils. Plant Sci 182:121-133

Etesami H, Hosseini M, Alikhani HA (2014) In planta selection of plant growth promoting endophytic bacteria for rice (Oryza sativa L.) J Soil Sci Plant Nutr 14(2):491-503

Gaiero JR, Mccall CA, Thompson KA, Day NJ, Best AS, Dunfield KE (2013) Inside the root microbiome: bacterial root endophytes and plant growth promotion. Am J Bot 100(9):1738-1750
Garbeva P, van Overbeek LS, van Vuurde JWL, van Elsas JD (2001) Analysis of endophytic bacterial communities of potato by plating and denaturing gradient gel electrophoresis (DGGE) of 16S rDNA based PCR fragments. Microbial Ecol 41:369-383

Germaine KJ, Keogh E, Ryan D, Dowling DN (2009) Bacterial endophyte-mediated naphthalene phytoprotection and phytoremediation. FEMS Microbiol Lett 296:226-234

Glick BR, Todorovic B, Czarny J, Cheng Z, Duan J, McConkey B (2007) Promotion of plant growth by bacterial ACC deaminase. Crit Rev Plant Sci 26:227-242

Gómez-Lama CC, Schilirò E, Valverde-Corredor A, Mercado-Blanco J (2014) The biocontrol endophytic bacterium Pseudomonas fluorescens PICF7 induces systemic defense responses in aerial tissues upon colonization of olive roots. Front Microbiol 5(427):1-14. doi:10.3389/fmicb.2014.00427

Hardoim PR, van Overbeek LS, van Elsas JD (2008) Properties of bacterial endophytes and their proposed role in plant growth. Trends Microbiol 10:463-471

Ho YN, Mathew DC, Hsiao SC, Shih CH, Chien MF, Chiang HM, Huang CC (2012) Selection and application of endophytic bacterium Achromobacter xylosoxidans strain F3B for improving phytoremediation of phenolic pollutants. J Hazard Mater 219-220: 43-49. doi:10.1016/j.jhazmat.2012.03.035

Huang XD, El-Alawi Y, Gurska J, Glick BR, Greenberg BM (2005) A multi-process phytoremediation system for decontamination of persistent total petroleum hydrocarbons (TPHs) from soils. Microchem J 81:139-147

Ikeda S, Okubo T, Anda M, Nakashita H, Yasuda M, Sato S, Kaneko T, Tabata S, Eda S, Momiyama A, Terasawa K, Mitsui H, Minamisawa K (2010) Community and genome-based views of plant-associated bacteria: plant-bacterial interactions in soybean and rice. Plant Cell Physiol 51(9):1398-1410

Khan S, Afzal M, Iqbal S, Khan QM (2013) Plant-bacteria partnerships for the remediation of hydrocarbon contaminated soils. Chemosphere 4:1317-1332

Kosaric N (2001) Biosurfactants and their application for soil bioremediation. Food Technol Biotechnol 39:295-304

Kukla M, Płociniczak T, Piotrowska-Seget Z (2014) Diversity of endophytic bacteria in Lolium perenne and their potential to degrade petroleum hydrocarbons and promote plant growth. Chemosphere 117:40-46

Li HY, Wei DQ, Shen M, Zhou ZP (2012) Endophytes and their role in phytoremediation. Fungal Divers 1(54):11-18

Lorck H (1948) Production of hydrocyanic acid by bacteria. Physiol Plantarum 1:142-146

Lumactud R, Shen SY, Lau M, Fulthorpe R (2016) Bacterial endophytes isolated from plants in natural oil seep soils with chronic hydrocarbon contamination. Front Microbiol 7:755. doi:10.3389/fmicb. 2016.00755

Naveed M, Mitter B, Yousaf S, Pastar M, Afzal M, Sessitsch A (2014) The endophyte Enterobacter sp. FD17: a maize growth enhancer selected based on rigorous testing of plant beneficial traits and colonization characteristics. Biol Fertil Soils 50:249-262

Nie Y, Chi CQ, Fang H, Liang JL, Lu SL, Lai GL, Tang YQ, Wu XL (2014) Diverse alkane hydroxylase genes in microorganisms and environments. Sci Rep 4:4968. doi:10.1038/srep04968

Oliveira V, Gomes NCM, Almeida A, Silva AMS, Simões MMQ, Smalla $\mathrm{K}$, Cunha Â (2014) Hydrocarbon contamination and plant species determine the phylogenetic and functional diversity of endophytic degrading bacteria. Mol Ecol 23:1392-1404

Oliveira V, Santos AL, Aguiar C, Santos L, Salvador AC, Gomes NCM, Silva H, Rocha SM, Almeida A, Cunha A (2012) Prokaryotes in salt marsh sediments of Ria de Aveiro: effects of halophyte vegetation on abundance and diversity. Estuar Coast Shelf Sci 110:61-68

Pacwa-Płociniczak M, Płaza GA, Piotrowska-Seget Z (2016) Monitoring the changes in a bacterial community in petroleum-polluted soil 
bioaugmented with hydrocarbon-degrading strains. Appl Soil Ecol 105:76-85

Pacwa-Płociniczak M, Płaza GA, Piotrowska-Seget Z, Cameotra SS (2011) Environmental applications of biosurfactants: recent advances Int J Mol Sci 18, 12, 1:633-654. doi:10.3390/ijms12010633

Patten CL, Glick BR (2002) Role of Pseudomonas putida indole acetic acid in development of the host plant root system. App Eniron Microbiol 68:3795-3801

Pawlik M, Piotrowska-Seget Z (2015) Endophytic bacteria associated with Hieracium piloselloides: their potential for hydrocarbonutilizing and plant growth-promotion. J Toxicol Env Heal A 78(13-14):860-870 org/10.1080/15287394.2015.1051200

Peng A, Liu J, Gao Y, Chen Z (2013) Distribution of endophytic bacteria in Alopecurus aequalis Sobol and Oxalis corniculata L. from soils contaminated by polycyclic aromatic hydrocarbons. PLoS One 8: 12. doi:10.1371/journal.pone.0083054

Pereira SIA, Monteiro C, Vega AL, Castro PML (2016) Endophytic culturable bacteria colonizing Lavandula dentata L. plants: isolation, characterization and evaluation of their plant growthpromoting activities. Ecol Eng 87:91-97

Phillips LA, Germida JJ, Farrell RE, Greer CW (2008) Hydrocarbon degradation potential and activity of endophytic bacteria associated with prairie plants. Soil Biol Biochem 12:3054-3064

Pikovskaya RI (1948) Mobilization of phosphorus in soil connection with vital capacity of source microbial species. Microbiologiya 17:362 370

Pilon-Smits EAH (2005) Phytoremediation. Annu Rev Plant Biol 56:1539

Płociniczak T, Sinkkonen A, Romantschuk M, Piotrowska-Seget Z (2013) Characterization of Enterobacter intermedius MH8b and its use for the enhancement of heavy metals uptake by Sinapis alba L. Appl Soil Ecol 63:1-7

Pointing SB (1999) Qualitative methods for the determination of lignocellulolytic enzyme production by tropical fungi. Fungal Divers 2:17-33

Porteous-Moore FP, Barac T, Borremans B, Oeyen L, Vangronsveld J, van der Lelie D, Campbell CD, Moore ER (2006) Endophytic bacterial diversity in poplar trees growing on a BTEX-contaminated site: the characterisation of isolates with potential to enhance phytoremediation. Syst Appl Microbiol 7:539-556

Preston GM (2004) Plant perceptions of plant growth-promoting Pseudomonas. Phil Trans R Soc Lond B 359:907-918

Qin S, Miao Q, Feng WW, Wang Y, Zhu X, Xing K, Jiang JH (2015) Biodiversity and plant growth promoting traits of culturable endophytic actinobacteria associated with Jatropha curcas L. growing in Panxi dry-hot valley soil. Appl Soil Ecol 93:47-55

Raaijmakers JM, de Bruijn I, de Kock MJD (2006) Cyclic lipopeptide production by plant-associated Pseudomonas spp.: diversity, activity, biosynthesis, and regulation. Mol Plant-Microbe Interact 19:699 710

Ryan RP, Germaine K, Franks A, Ryan DJ, Dowling DN (2008) Bacterial endophytes: recent developments and applications. FEMS Microbiol Lett 278:1-9

Santoyo G, Moreno-Hagelsie G, del Carmen O-MM, Glick BR (2016) Plant growth-promoting bacterial endophytes. Microbiol Res 183: 92-99

Schwyn B, Neilands JB (1987) Universal chemical assay for the detection and determination of siderophores. Anal Biochem 160:47-56

Seghers D, Wittebolle L, Top EM, Verstraete W, Siciliano SD (2004) Impact of agricultural practices on the Zea mays L. endophytic community. Appl Environ Microbiol 70:1475-1482

Sessitsch A, Kuffner M, Kidd P, Vangronsveld J, Wenzel W, Fallmann K, Puschenreiter M (2013) The role of plant-associated bacteria in the mobilization and phytoextraction of trace elements in contaminated soils. Soil Biol Biochem 60:182-194
Siciliano SD, Fortin N, Mihoc A, Wisse G, Labelle S, Beaumier D, Ouellette D, Roy R, Whyte LG, Banks MK, Schwab P, Lee K, Greer CW (2001) Selection of specific endophytic bacterial genotypes by plants in response to soil contamination. Appl Environ Microbiol 6:2469-2475

Sun K, Liu J, Jin L, Gao Y (2014b) Utilizing pyrene-degrading endophytic bacteria to reduce the risk of plant pyrene contamination. Plant Soil 374:251-262

Sun K, Liu L, Gao Y, Jin L, Gu Y, Wang W (2014a) Isolation, plant colonization potential, and phenanthrene degradation performance of the endophytic bacterium Pseudomonas sp. Ph6-gfp Sci Rep 4: 5462, DOI: $10.1038 /$ srep05462

Sun Y, Cheng Z, Glick BR (2009) The presence of a 1aminocyclopropane-1-carboxylate (ACC) deaminase deletion mutational ters the physiology of the endophytic plant growth-promoting bacterium Burkholderia phytofirmans PsJN. FEMS Microbiol Lett 296:131-136

Taghavi S, Garafola C, Monchy S, Newman L, Hoffman A, Weyens N, Barac T, Vangronsveld J, van der Lelie D (2009) Genome survey and characterization of endophytic bacteria exhibiting a beneficial effect on growth and development of poplar trees. Appl Environ Microbiol 75(3): 748-757

Tardif S, Yergeau É, Tremblay J, Legendre P, Whyte LG, Greer CW (2016) The willow microbiome is influenced by soil petroleumhydrocarbon concentration with plant compartment-specific effects. Front Microbiol 7:1363. doi:10.3389/fmicb.2016.01363

Thijs S, van Dillewijn P, Sillen W, Truyens S, Holtappels M, D'Haen J, Carleer R, Weyens N, Ameloot M, Ramos JL, Vangronsveld J (2014) Exploring the rhizospheric and endophytic bacterial communities of Acer pseudoplatanus growing on a TNT-contaminated soil: towards the development of a rhizocompetent TNT-detoxifying plant growth promoting consortium. Plant Soil 385:15-36

van Beilen JB, Funhoff EG, van Loon A, Just A, Kaysser L, Bouza M, Holtackers R, Rothlisberger M, Li Z, Witholt B (2006) Cytochrome P450 alkane hydroxylases of the CYP153 family are common in alkane-degrading eubacteria lacking integral membrane alkane hydroxylases. Appl Environ Microbiol 72(1):59-65

van Bogaert INA, Groeneboer S, Saerens K, Soetaert W (2011) The role of cytochrome $\mathrm{P} 450$ monooxygenases in microbial fatty acid metabolism. FEBS J 278:206-221

Vangronsveld J, Herzig R, Weyens N, Boulet J, Adriaensen K, Ruttens A, Thewys T, Vassilev A, Meers E, Nehnevajova E, van der Lelie D, Mench M (2009) Phytoremediation of contaminated soils and groundwater: lessons from the field. Environ Sci Pollut Res 16: 765-794

Velho RV, Medina LFC, Segalin J, Brandelli A (2011) Production of lipopeptides among Bacillus strains showing growth inhibition of phytopathogenic fungi. Folia Microbiol 56:297-303

Verma SC, Ladha JK, Tripathi AK (2001) Evaluation of plant growth promoting and colonization ability of endophytic diazotrophs from deep water rice. J Biotechnol 91:127-141

Wael SE, Abdellah A, Moustafa YE, Medhat E (2014) In vitro antagonistic activity, plant growth promoting traits and phylogenetic affiliation of rhizobacteria associated with wild plants grown in arid soil. Front Microbiol 5(651):1-11

Wang J, Zhang Z, Su Y, He W, He F, Song H (2008) Phytoremediation of petroleum polluted soil. Pet Sci 5:167-171

Weyens N, Taghavi S, Barac T, van der Lelie D, Boulet J, Artois T, Carleer R, Vangronsveld J (2009a) Bacteria associated with oak and ash on a TCE-contaminated site: characterization of isolates with potential to avoid evapotranspiration. Environ Sci Pollut Res $16: 830-843$

Weyens N, van der Lelie D, Artois T, Smeets K, Taghavi S, Newman L, Carleer R, Vangronsveld J (2009b) Bioaugmentation with engineered endophytic bacteria improves phytoremediation. Environ Sci Technol 43:9413-9418 
Weyens N, van der Lelie D, Taghavi S, Newman L, Vangronsveld J (2009d) Exploiting plant-microbe partnerships for improving biomass production and remediation. Trends Biotechnol 27:591-598

Weyens N, van der Lelie D, Taghavi S, Vangronsveld J (2009c) Phytoremediation: plant-endophyte partnerships take the challenge. Curr Opin Biotechnol 2:248-254

Xu JY, Han YH, Chen Y, Zhu LJ, Ma LQ (2016) Arsenic transformation and plant growth promotion characteristics of As-resistant endophytic bacteria from As-hyperaccumulator Pteris vittata. Chemosphere 144:1233-1240

Yousaf S, Afzal M, Reichenauer TG, Brady CL, Sessitsch A (2011) Hydrocarbon degradation, plant colonization and gene expression of alkane degradation genes by endophytic Enterobacter ludwigii strains. Environ Pollut 10:2675-2683

Yousaf S, Andria V, Reichenauer TG, Smalla K, Sessitsch A (2010a) Phylogenetic and functional diversity of alkane degrading bacteria associated with Italian ryegrass (Lolium multiflorum) and Birdsfoot trefoil (Lotus corniculatus) in a petroleum oil-contaminated environment. J Hazard Mater 1-3:523-532

Yousaf S, Ripka K, Reichenauer TG, Andria V, Afzal M, Sessitsch A (2010b) Hydrocarbon degradation and plant colonization by selected bacterial strains isolated from Italian ryegrass and birdsfoot trefoil. J Appl Microbiol 4(109):1389-1401

Zampolli J, Collina E, Lasagni M, Gennaro P (2014) Biodegradation of variable-chain-length $n$-alkanes in Rhodococcus opacus $\mathrm{R} 7$ and the involvement of an alkane hydroxylase system in the metabolism. AMB Express 4(73):1-9. doi:10.1186/s13568-014-0073-4

Zúñiga A, Poupin MJ, Donoso R, Ledger T, Guiliani N, Gutiérrez RA, González B (2013) Quorum sensing and indole-3-acetic acid degradation play a role in colonization and plant growth promotion of Arabidopsis thaliana by Burkholderia phytofirmans PsJN. Mol Plant-Microbe Interact 26:546-553 